\title{
INTRODUKSI TEKNOLOGI PENGOLAHAN DAUN KELOR YANG MENDUKUNG EKONOMI MASYARAKAT DI POSDAYA BERINGIN SAKTI
}

\author{
Zasmeli Suhaemi $^{\left({ }^{*}\right)}$, Wartis Anwar ${ }^{1)}$, Titi Sumarni ${ }^{1)}$, Mahyudi Irgantoro ${ }^{1)}$ dan Yusniati $^{2)}$ \\ ${ }^{1)}$ Fakultas Pertanian, Universitas Tamansiswa; \\ ${ }^{2)}$ Fakultas Kedokteran, Universitas Andalas \\ ${ }^{*}$ Email: emizasmeli@gmail.com
}

\begin{abstract}
ABSTRAK
Tanaman Kelor (Moringa oleifera) sangat mudah dikembang biakan, dan tidak membutuhkan tanah dengan kualifikasi khusus serta bersifat tahunan, sehingga tidak memberatkan masyarakat dalam pengelolaannya. Hasil tanaman kelor dapat dijadikan peluang usaha dibidang obat-obatan herbal seperti teh kelor, atau dibuat pangan fungsional seperti Mie Kelor. Dengan adanya usaha tersebut, dapat mengajak masyarakat untuk melakukan pengelolaan tamanan kelor yang bernilai ekonomis atau di konsumsi langsung oleh masyarakat, sehingga tetap sehat serta pendapatan meningkat. Untuk meningkatkan pengetahuan masyarakat tentang pengembangan dan pengolahan tanaman Kelor, dilakukan tahapan: 1) Sosialisasi; 2) Pelatihan, dan 3) Pendampingan. Berdasarkan dari hasil kegiatan dapat disimpulkan bahwa tanggapan masyarakat akan sesuatu yang baru dan bermanfaat bagi kehidupan sangat tinggi. Ini ditunjukkan dengan peningkatan persentase hasil implementasi setiap langkah kegiatan. Saat awal kegiatan, 91,30 \% peserta yang hadir dalam sosialisasi tanaman Kelor belum mengetahui manfaat tanaman tersebut. Namun diakhir kegiatan $100 \%$ peserta pelatihan yang telah diajarkan pembuatan Teh kelor, telah mampu secara mandiri dan membentuk Kelompok Usaha Bersama (KUB) dengan nama Beringin Sakti. Saat ini teh Kelor hasil olahan masyarakat mitra telah dijual Rp 10.000,- per kemasan isi 25 gram, yang didapatkan dari satu batang tanaman Kelor. Hasil kalkulasi menunjukkan bahwa dengan menanam 40 batang Kelor, dapat menambah pendapatan masyarakat minimal Rp. 1 juta per bulan.
\end{abstract}

Kata Kunci: moringa oleifera, teh kelor, mie kelor

\section{Technology Introduction on Processing Moringa oleifera in Posdaya Beringin Sakti}

\begin{abstract}
Moringa plants (Moringa Oleifera) are very easy to grow and do not need special qualifications land and are an annual nature, so it does not burden the society in its management. Moringa products could be a business opportunities of herbal medicine field such as Moringa tea, and Moringa noodle. Such business could invite the society to manage Moringa plants that the result could be sold and consume by them, to get healthy life and more income. In order to giving more knowledge about Moringa tree and management to society, the steps are: 1) Socialization, 2) Training, and 3) Associating. Based on those activities, it conclude that society respond to something new and beneficial for life are high. It is proven by the enthusiasm of community. One of Moringa products are Merungai tea and Moringa noodle. Nowadays, the society had sell Moringa tea Rp. 10,000,- per 25gr packages that produce by one three of Moringa. The calculation result on development and management 40 trees could reach up to Rp. $1,000,000,-$ income per month in minimal number.
\end{abstract}

Keywords: moringa oleifera, moringa tree, moringa noodle.

\section{PENDAHULUAN}

Pembangunan desa pada hakikatnya adalah segala bentuk aktivitas manusia (masyarakat dan pemerintah) di desa dalam membangun diri, keluarga, masyarakat dan 
lingkungan di wilayah desa baik yang bersifat fisik, ekonomi, sosial, budaya, politik, ketertiban, pertahanan dan keamanan, agama dan pemerintahan yang dilakukan secara terencana dan membawa dampak positif terhadap kemajuan desa. Pembangunan desa sesungguhnya merupakan upaya-upaya sadar dari masyarakat dan pemerintah baik dengan menggunakan sumberdaya yang bersumber dari desa, bantuan pemerintah maupun bantuan organisasi-organisasi/lembaga domestik maupun internasional untuk menciptakan perubahan-perubahan ke arah yang lebih baik. Secara umum, pembangunan desa meliputi dua aspek utama, yaitu pembangunan desa dalam aspek fisik dan pembangunan dalam aspek pemberdayaan insani (Muhi, 2011).

Pemberdayaan masyarakat adalah upaya untuk memberikan daya (empowerment) atau penguatan (strengthening) kepada masyarakat. Pemberdayaan masyarakat juga diartikan sebagai kemampuan individu yang bersenyawa dengan masyarakat dalam membangun keberdayaan masyarakat yang bersangkutan sehingga bertujuan untuk menemukan alternatif-alternatif baru dalam pembangunan masyarakat (Mardikanto, 2014).

Alternatif baru dapat berupa keterampilan usaha dalam pemanfaatan lahan tidur dan pekarangan yang dapat dengan mudah dilakukan oleh masyarakat. Keterampilan tersebut diharapkan dapat menjadi sumber pendapatan yang baru bagi keluarga. Pemberian pelatihan dan penyuluhan yang jelas kepada masyarakat berupa pengetahuan keterampilan usaha, akan dapat menekan angka penangguran dan meningkatkan pendapatan keluarga. Pemahaman keterampilan usaha ini akan dapat ditularkan terus menerus antar sesama masyarakat sehingga tercipta pembangunan berkelanjutan. Karena masyarakat seharusnya diberi kesempatan memahami sendiri tentang seluk beluk pembangunan, menumbuhkan rasa memiliki dari masyarakat dan pada sisi lain akan mengurangi rasa apriori masyarakat (Purba, 2008).

Posdaya Beringin Sakti berada di Kelurahan Koto Baru Nan XX Kecamatan Lubuk Begalung, Kota Padang Sumatera Barat. Kelurahan Koto Baru Nan XX terbagi menjadi 6 RW dengan Topografi Desa Datar 100\%. Beriklim basah, Curah Hujan 200 mm, Jumlah Bulan Hujan 9 bulan, Kelembaban 40,00, Suhu Rata - Rata 30,00 ${ }^{\circ} \mathrm{C}$, Ketinggian Tempat 12,00 mdpl.

Kelurahan Koto Baru Nan XX berjarak dari pusat Pemerintahan Kecamatan 6 Km, Jarak dari Pusat Kabupaten $13 \mathrm{Km}$, Jarak dari Pusat Ibu kota Provinsi $13 \mathrm{Km}$ dengan Jumlah Penduduk 8.531 Jiwa yang terdiri dari 2.578 KK, Laki-laki 4.225 Jiwa, Perempuan 4.306 Jiwa, dengan mayoritas pekerjaan pedagang kecil dan buruh. Tingkat pendidikan masyarakat Sekolah Dasar 190 Orang SMP 181 Orang SMA / SMU 73 Orang Akademi /D1 - D3 15 Orang Sarjana 33 Orang (BPS, 2017).

Posdaya Beringin Sakti berada di wilayah RW II Kelurahan Koto Baru nan XX merupakan suatu wilayah yang terdapat di Kecamatan Lubuk Begalung, Kota Padang, Provinsi Sumatera Barat, dengan jumlah warga $284 \mathrm{KK}$ yang rata-rata tergolong ekonomi menengah kebawah. Wilayah tersebut ditemukan lahan-lahan kosong seluas 100-500 m2 yang tidak dimanfaatkan dan sebagian besar dijadikan tempat pembuangan sampah, sehingga menyebabkan rusaknya lingkungan dan menjadi sarang berbagai penyakit yang mengakibatkan dampak buruk bagi kesehatan masyarakat disekitarnya.

Lahan kosong apabila dikelola dengan baik akan menjadi sesuatu yang bermanfaat dan berdampak positif seperti dijadikan perkebunan tanaman kelor (Moringa oleifera). Tanaman ini sangat mudah dikembang biakan, dan tidak membutuhkan tanah dengan kualifikasi khusus serta bersifat tahunan, sehingga tidak memberatkan masyarakat 
dalam pengelolaannya.

Di Indonesia kelor memiliki nama lain, diantaranya kelor (jawa, sunda, bali, lampung, kilor (lampung), murong (aceh), munggai (sumatera barat), kerol (buru), marangghi (madura), moltong (flores), kelo (ternate, tidore), ongge (bima) dan hau fo (timor). Berdasarkan uji fitokimia pada daun kelor adalah positif mengandung flavonoid (Immy, Aryanti and Suripto, 2015). Setiap bagian tanaman Kelor memiliki kandungan kimia yag bervariasi, daun dan biji serta bunga tanaman ini banyak digunakan sebagan bahan untuk pangan fungsional (food fortificant) dalam pembuatan roti, biskuit, yoghurt, keju atau sup (Oyeyinka and Oyeyinka, 2016). Daun Kelor (Moringa oleifera), kaya akan mineral, vitamin dan kadungan fitokimia. Ekstrak daun Kelor banyak digunakan dalam banyak percobaan dibidang malnutrisi, memperlancar ASI. Juga berpotensi sebagai antioksidan, anti kanker, anti inflammatory, anti diabet dan anti mikroba (Gopalakrishnan, Doriya and Kumar, 2016). Daun kelor juga bermanfaat bagi kesehatan, seperti pengobatan penyakit bronkhitis dan gangguan pernafasan, juga ampuh mengobati penyakit diabetes, hepatitis, jantung, kolestrol tinggi, gizi buruk, mata minus, plus dan selinder.

Hasil tanaman kelor dapat dijadikan peluang usaha dibidang obat-obatan herbal dan kuliner pangan fungsional, seperti halnya teh Kelor. Dengan adanya usaha tersebut, bisa mengajak masyarakat untuk melakukan pengelolaan tamanan kelor yang hasilnya bisa dijual atau di konsumsi oleh masyarakat, sehingga tetap sehat, pendapatan keluarga bertambah, dan ekonomi masyarakat setempat akan meningkat, menjadikan masyarakat lebih sejahtera, terutama di masa sekarang dengan biaya kebutuan hidup semakin meningkat tajam.

Pertanian abad ke 21 bagi negara-negara yang sedang berkembang harus mampu menciptakan sistem pertanian yang memiliki produktivitas tinggi tetapi dengan low cost input. Pembangunan pertanian sebagai bagian integral dari pembangunan wilayah akan meningkat investasi dibidang usaha pertanian yang serasi dengan keadaan sosial ekonomi daerah, kesesuaian lahan dan potensi pasar (Pasandaran et al., 2006).

\section{METODE}

Tanaman daun kelor belum banyak di kembangkan di kota padang karena pengetahuan masyarakat yang minim tentang tanaman ini. Sedangkan dikota kota besar lainnya sudah mengembangkan bahkan sudah dijadikan peluang usaha seperti bahan campuran makanan maupun untuk dijadikan bahan pengobatan, sehingga lahan yang kosong tersebut dijadikan budidaya tanaman daun kelor maka kegiatan ini meliputi sebagai berikut: penyuluhan, pelatihan, percontohan, pendampingan, dan evaluasi, sehingga munculnya usaha baru dalam pegelolaan daun Kelor seperti teh Kelor dan mie Kelor.

Untuk meningkatkan pengetahuan masyarakat di Kelurahan Koto Baru Nan XX Kec. Lubuk Begalung tentang budidaya Kelor dan pengolahan Kelor, dilakukan pendekatan yaitu (Novia et al., 2018) :

1. Sosialisasi

2. Pelatihan

3. Percontohan

4. Pendampingan 
Anggota masyarakat yang ikut serta di setiap tahapan, dilakukan survay untuk mendeskripsikan implementasi setiap hasil kegiatan. Hasil survay dianalisis secara deskriptif, berdasarkan persentase peserta kegiatan yang berhasil sesuai kriteria yang diberikan. Tim pelaksana kegiatan memantau dan mengevaluasi hasil kegiatan setiap minggu. Pendampingan dilakukan untuk seluruh peserta sasaran sampai berhasil memasarkan produk olahan daun Kelor secara Mandiri.

\section{HASIL DAN PEMBAHASAN}

Kegiatan ini diimplementasikan dengan tahapan-tahapan untuk menjamin kegiatan yang dilakukan dapat diaplikasikan oleh peserta kegiatan dari angota Posdaya Beringin Sakti di Kelurahan Koto Baru Nan XX, Kecamatan Lubuk Begalung. Sesui teori yang dijelaskan Najiati dkk, (2005) bahwa terdapat empat prinsip yang sering digunakan untuk suksesnya program pemberdayaan, yaitu prinsip kesetaraan, partisipasi, keswadayaan atau kemandirian, dan berkelanjutan. Program pemberdayaan yang dapat menstimulasi kemandirian masyarakat adalah program yang sifatnya partisipatif, direncanakan, dilaksanakan, diawasi, dan dievaluasi oleh masyarakat(Novia et al., 2018). Namun, untuk sampai pada tingkat tersebut perlu waktu dan proses pendampingan yang melibatkan pendamping yang berkomitmen tinggi terhadap pemberdayaan masyarakat. Hasil setiap tahapan dilakukan survay sehingga memberikan gambaran tingkat partisipasi masyarakat, seperti terlihat pada Tabel 1.

Tabel 1. Hasil Survay Kegiatan Penerapan IPTEKS

\begin{tabular}{rll}
\hline No & \multicolumn{1}{c}{ Kegiatan } & \multicolumn{1}{c}{ Hasil Survay } \\
\hline 1 & Sosialisasi Tanaman Kelor & $91,30 \%$ baru mengetahui manfaat Tanaman Kelor \\
2 & Pelatihan Pembibitan & $64,29 \%$ berhasil membibitkan di rumah masing-masing \\
3 & Pelatihan pembuatan Teh Kelor & $71,43 \%$ berhasil membuat Teh Kelor \\
4 & Pelatihan pembuatan Mie Kelor & $64,29 \%$ telah mempraktekan di rumah \\
5 & Memasarkan Teh Kelor & $100 \%$ Telah menjual Teh Kelor dengan membentuk KUB \\
\hline
\end{tabular}

\section{Sosialisasi}

Hasil survay menunjukkan bahwa 91,3 \% peserta sosialisasi baru mendapat pengetahuan mengenai tanaman Kelor serta manfaatnya (Tabel 1). Sosialisasi di laksanakan pada tanggal 10 Agustus 2018 di kantor Kelurahan Koto Baru Nan XX Kec. Lubuk Begalung kota padang. Sosialisai tersebut dihadiri oleh Bapak Lurah dan Bapak Ketua RT beserta anggota Posdaya Beringin Sakti. Dalam kegiatan sosialisasi tanaman kelor, dijelaskan tentang manfaat dari tanaman kelor. Kegiatan sosialisasi berjalan dengan lancar sampai akhir acara, dalam kegiatan sarsana dan prasarana disediakan oleh kelurahan setempat beserta ibu ketua posdaya, dalam kegiatan ini kita mendapatkan sambutan dengan baik dari Bapak Lurah dan anggota posdaya beringin sakti, dimana pada kegiatan ini banyak dari anggota posdaya yang bertanya seputar tanaman kelor tidak hanya bertanya ada juga dari anggota posdaya yang memberikan pendapat tentang tanaman kelor yang ternyata sebelumnya sudah mengetahui bentuk tanaman kelor tapi tidak mengetahui nama dari tanaman kelor ini, serta ada yang baru mengenal tanaman kelor dan berantusias untuk membudidayakan dan mengkonsumsi tanaman kelor yang 
baik untuk kesehatan.

Karena tanaman ini memang telah berekembang biak di pulau Jawa namun masih belum banyak diketahui orang di Sumatera Barat umumnya dan Padang khususnya. Hasil analisa laboratorium Politani Payakumbuh (2018) menggambarkan nilai gizi daun Kelor yang sangat tinggi sehingga disebut Mirracle of tree”. Selain nilai gizi yang tinggi, kandungan antioksidan daun Kelor sangat banyak (Tabel 2), sehingga sangat baik untuk kesehatan dalam upaya menangkal radikal bebas. Maka penting jadinya jika masyarakat Padang atau Sumatera Barat mulai mengembangbiakan tanaman Kelor. Karena kesalahan menu makan dapat mengakibatkan terbentuknya radikal bebas dalam tubuh, apabila bereaksi dengan senyawa polutif akan berubah menjadi racun bagi tubuh, yang dapat merusak fungsi sel tubuh dan menyebabkan timbulnya berbagai macam penyakit degenerative (Hernani and Raharjo, 2005).

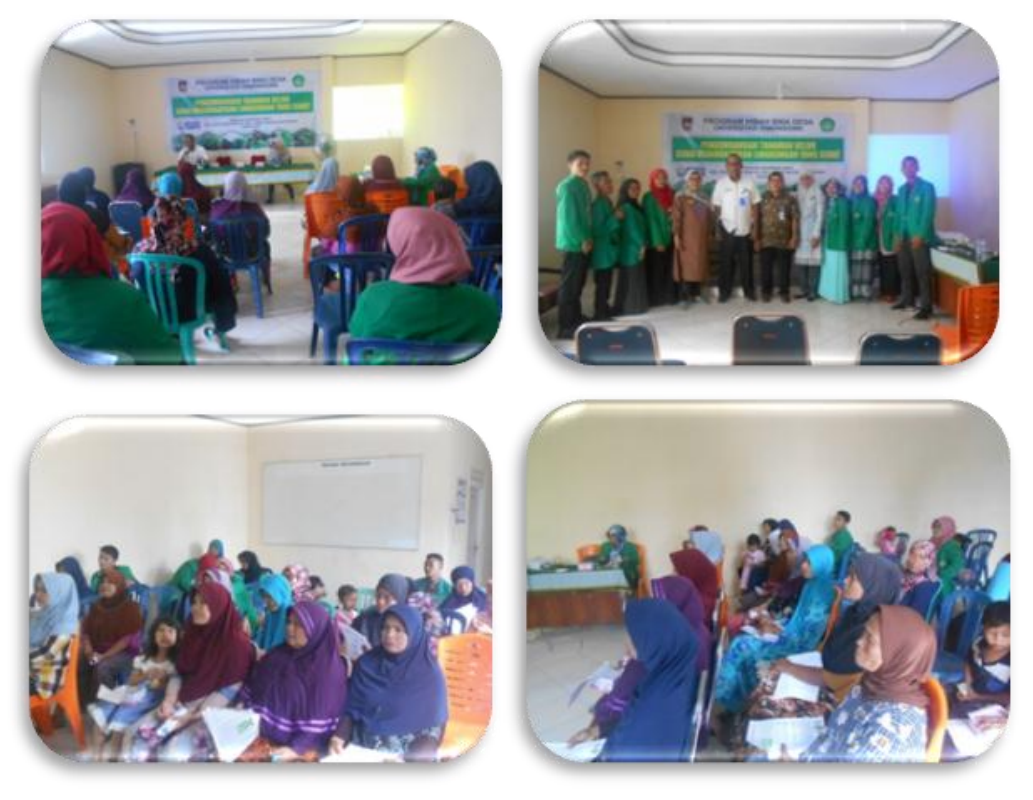

Gambar 1. Sosialisasi Pengembangan Tanaman Kelor Dan Manfaatnya

Tabel 2. Kandungn Gizi Daun Kelor Kering

\begin{tabular}{llr}
\hline No & & Nutrisi \\
\hline 1 & Kadar Air (\%) & Kandungan \\
2 & Kadar Abu (\%) & 12,14 \\
3 & Kadar Protein (\%) & 10,87 \\
4 & Kadar Lemak (\%) & 29,60 \\
5 & Serat Kasar (\%) & 2,91 \\
6 & Kadar Calsium (\%) & 32,89 \\
7 & Kadar Pospor (\%) & 4,99 \\
8 & Karbohidrat (\%) & 0,54 \\
9 & Antioksidan (ppm) & 11,59 \\
\hline
\end{tabular}

Sumber: Hasil analisis Laboratorium Politani Payakumbuh, 2018 


\section{Pelatihan}

Setelah disosialisasikan manfaat tanaman Kelor, masyarakat diajak untuk mengembangkan tanaman tersebut melalui pelatihan budidaya, pengolahan menjadi teh dan olahan pangan sehat berupa Mie Kelor, agar memberi manfaat secara ekonomis.

Berdasarkan hasil sosialisasi bahwa masih banyak masyarakat yang belum mengetahui manfaat tanaman Kelor, maka dibutuhkan pengetahuan untuk membudidyakan tanaman Kelor agar masyarakat dapat mengembangbiakan secara mandiri untuk kelanjutan kegiatan. Pemberdayaan masyarakat adalah upaya untuk memampukan dan memandirikan masyarakat (Fahrudin, 2012). Salah satu upaya tersebut adalah Empowering, yaitu meningkatkan kapasitas dengan memperkuat potensi atau daya yang dimiliki oleh masyarakat. Perkuatan ini meliputi langkah-langkah nyata seperti penyediaan berbagai masukan (input) serta pembukaan akses kepada berbagai peluang yang dapat membuat masyarakat menjadi makin berdaya.

Berdasarkan Tabel 1, didapatkan hasil bahwa $64,29 \%$ berhasil membibitkan di rumah masing-masing. Pelatihan pembibitan dilakukan di PAUD Beringin Sakti, Kelurahan Koto Baru Nan XX Kecamatan Lubuk Begalung pada tanggal 5 September 2018, tahapan awal yaitu pengenalan tanaman Kelor dan manfaat tanaman kelor di dalam ruangan kepada ibu-ibu anggota posdaya lalu dilanjutkan di luar ruangan yaitu pembibitan Kelor.

Pelatihan pembibitan Kelor, diberikan dengan 2 cara, yaitu dengan stek dan biji. Pembibitan kelor dengan cara di stek yaitu menggunaan batang dari tanaman kelor yang dipotong sepanjang $20 \mathrm{~cm}$ kemudian di tanam ke dalam polybag dengan cara sedikit dimiringkan, kemudian di siram dan di letakkan di tempat yang ternaungi agar tidak terpapar sinar matahari langsung.

Pembibitan dengan cara pembenihan, yaitu pertama biji tanaman kelor di buka kulit lapisan luar, setelah itu di rendam dalam air selama 6 jam, tujuannya yaitu untuk menyeleksi benih yang baik, benih yang tidak mengapung itulah benih yang baik untuk di tanam. Untuk penananman ada 2 cara yang petama biji tanaman kelor yang sudah di rendam di triskan dan ditanam ke dalam polibek, dan yang kedua menggunakan media tanam tisu/kapas seperti perkecambahan setelah tanaman memiliki daun 4 lembar kemudian di pindah ke polybag.

Pada saat kegitan, Tim pelaksana telah menyiapkan contoh dari masing-masing pembibitan, dan langsung memperagakan cara pembibitan yang baik dan benar. Setelah kegiatan pelatihan budidaya tanaman Kelor, tim memberikan biji Kelor dan polybag kepada ibu-ibu peserta untuk di tanam di pekarangan rumah. Untuk menambah semangat dari ibu-ibu peserta pelatihan, tim membari reward kepada peserta yang berhasil membibitkan tanaman Kelor dengan baik. 


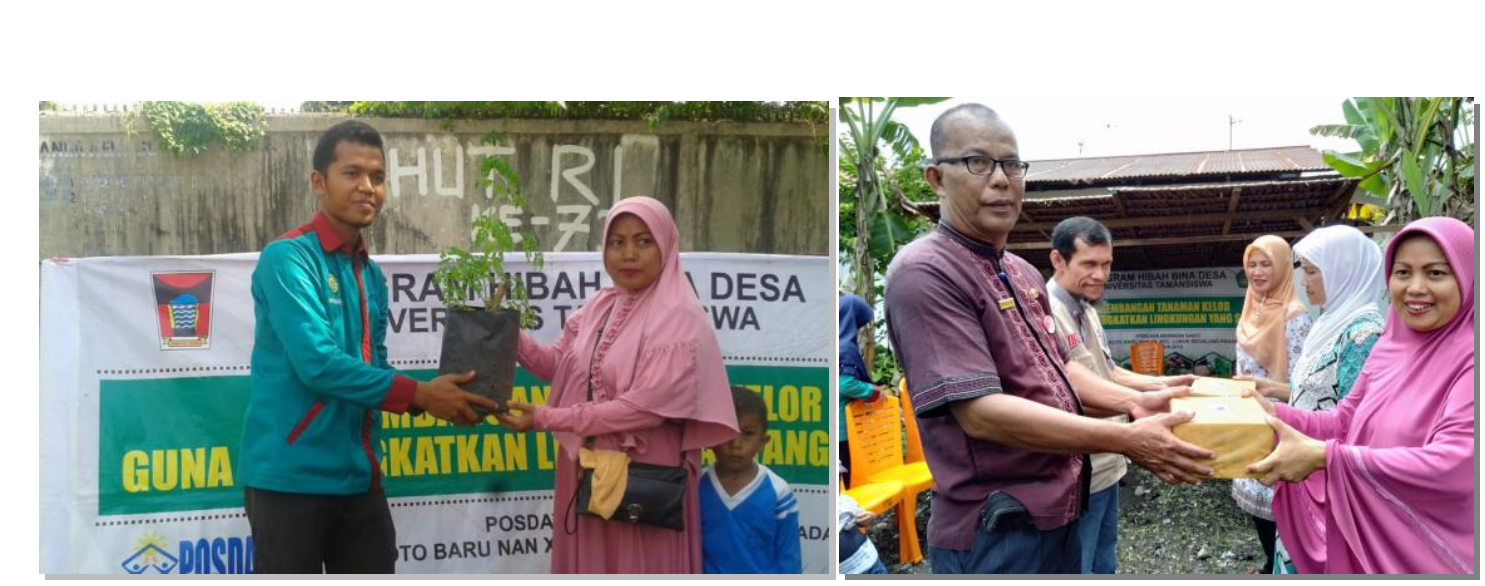

Gambar 2. Pemberian Hadiah Kepada Peserta Yang Paling Baik Pembibitannya

Sebagai jaminan keberlanjutan program, masyarakat Mitra juga diberikan pelatihan pengolahan daun Kelor berupa teh Kelor dan Mie Kelor. Pelatihan pembuatan teh kelor dan Mie Kelor dilakukan di PAUD Beringin Sakti, Kelurahan Koto Baru Nan XX Kec. Lubuk Begalung. Pada kegiatan ini dijelaskan cara pembuatan teh kelor mulai dari cara pemanenan daun kelor sampai menjadi teh kelor. Hasil pelatihan telah dapat diimplementasikan oleh peserta sebanyak 71,43\% (Tabel 1). Hasil ini menunjukkan bahwa antusias peserta pelatihan cukup besar, dikarenakan manfaat tanaman Kelor sudah mulai dirasakan oleh peserta. Peserta pelatihan telah berhasil membuat teh Kelor dengan kemasan sederhana untuk berat 12 gram dan 25 gram, dengan harga jual ke konsumen langsung Rp. 5.000,- dan Rp. 10.000,-. Sebagaimana sebuah pendapat bahwa pembangunan pertanian sebagai bagian integral dari pembangunan wilayah akan meningkat investasi dibidang usaha pertanian yang serasi dengan keadaan sosial ekonomi daerah, kesesuaian lahan dan potensi pasar (Pasandaran et al., 2006).
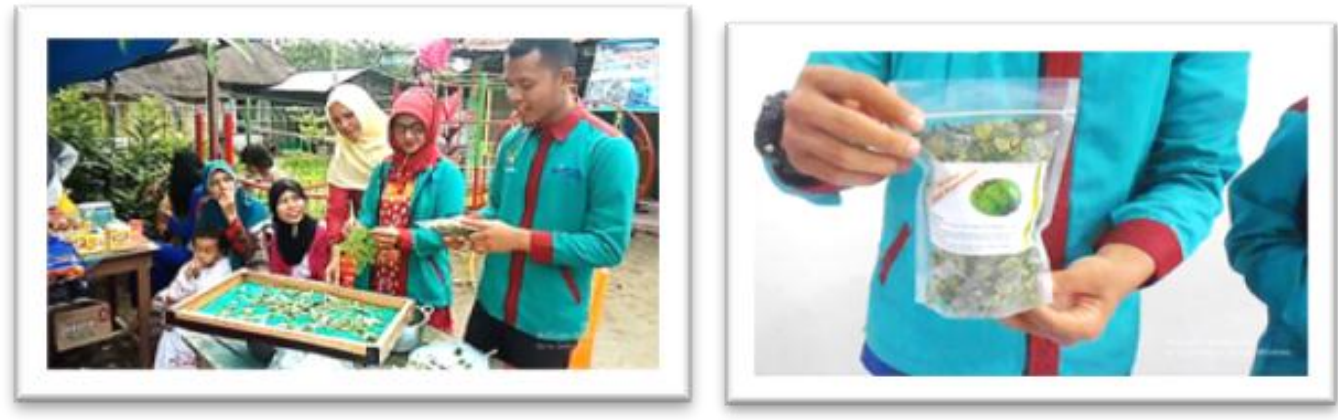

Gambar 3. Pelatihan Pembuatan Teh Kelor, Dan Kemasan Isi 25 Gram 

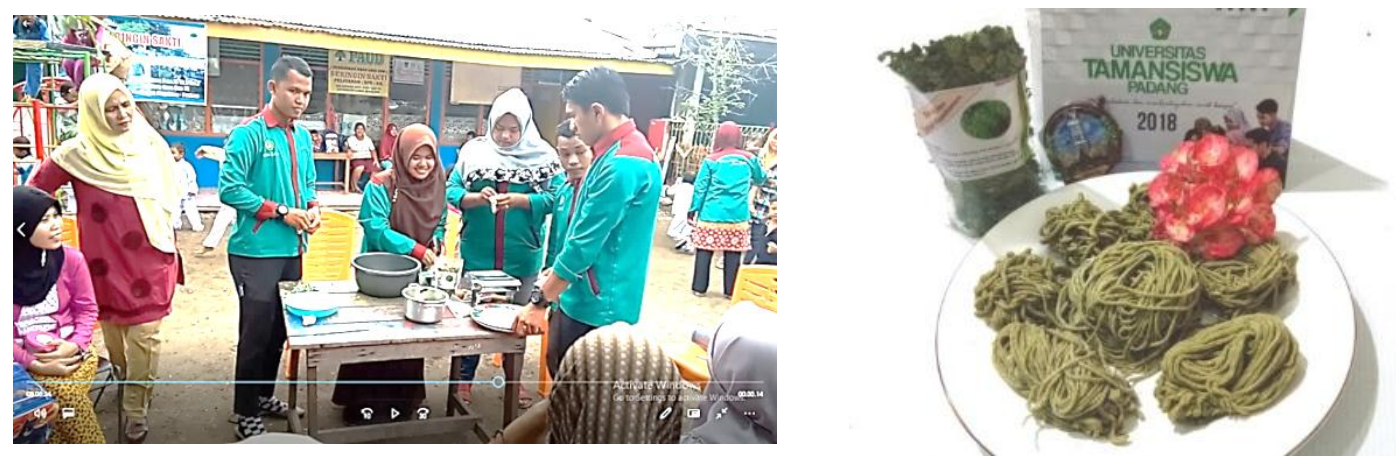

Gambar 4. Pelatihan Pembuatan Mie Kelor Dan Mie Kelor Yang Telah Siap Diolah

\section{Percontohan}

Pembuatan kebun kelor demplot dilaksanakan di Kelurahan Koto Baru Nan XX, Kecamatan Lubuk Begalung Kota Padang. Pembuatan kebun kelor ini bertujuan untuk dijadikan kebun percontohan bagi masyarakat Kelurahan Koto Baru Nan XX khususnya Posdaya Beringin Sakti.

Survei tempat dipandu oleh ketua Posdaya Beringin Sakti dimana lokasi yang digunakan untuk pembuatan kebun kelor merupakan lahan yang tidak dimanfaatkan oleh masyarakat hanya sebagai tempat pembuangan sampah rumah tangga yang banyak ditumbuhi semak belukar, sehingga lokasi tersebut untuk dijadikan sebagai kebun percontohan tanaman kelor. Pembuatan naungan bertujuan untuk sebagai tempat penyemaian bibit kelor sebelum dipindahkan ke kebun percontohan. Pembuatan naungan dilaksakan bersama-sama dengan anggota Posdaya Beringin Sakti.
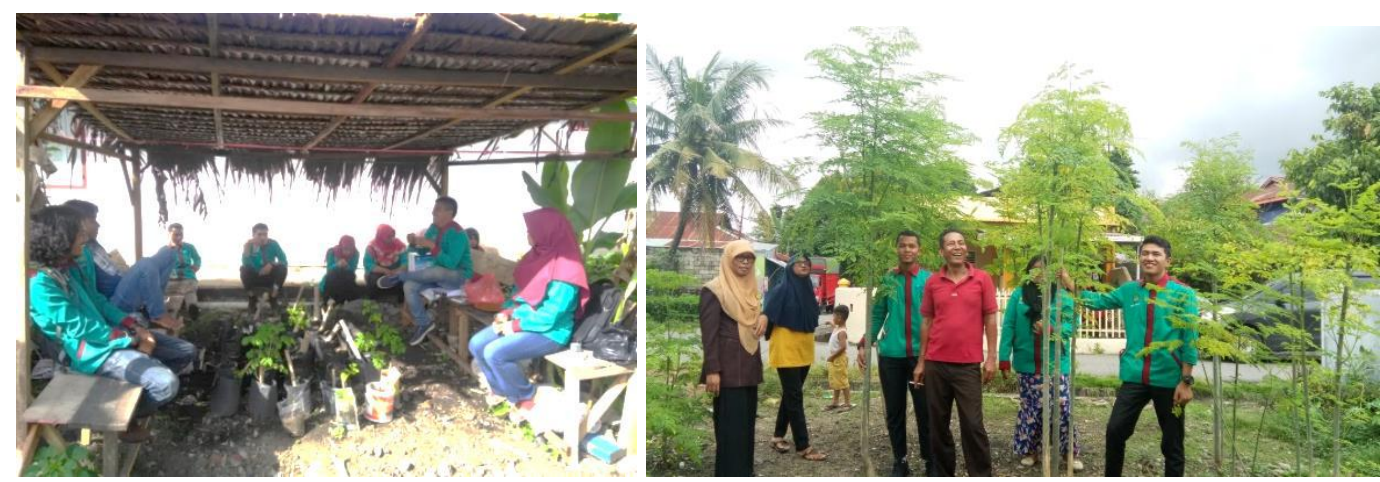

Gambar 5. Naungan Pembibitan dan Kebun Kelor Demplot di Posdaya Beringin Sakti

\section{Pendampingan}

Guna menjamin keberlanjutan dilakukan pendampingan terhadap peserta pelatihan, sehingga $100 \%$ peserta telah bisa memasarkan daun Kelor kering (Tabel 1). Hal ini disebabkan mulai meluasnya pengetahuan masyarakat akan manfaat daun Kelor. Seperti disebutkan bahwa Daun Kelor (Moringa oleifera), kaya akan mineral, vitamin dan kadungan fitokimia. Ekstrak daun Kelor banyak digunakan dalam banyak percobaan dibidang malnutrisi, memperlancar ASI. Juga berpotensi sebagai antioksidan, anti kanker, anti inflammatory, anti diabet dan anti mikroba (Gopalakrishnan, Doriya and 
Kumar, 2016).

Akibat begitu besar minat peserta untuk meningkatkan pendapatan, maka peserta sepakat untuk membentuk Kelompok Usaha Bersama (KUB) Beringin Sakti dengan fokus usaha penjualan bibit tanaman kelor dan teh dari daun kelor. Akibat adanya program ini, posyandu di Keluruhan Koto Baru Nan XX, Kecamatan Lubuk Begalung, mendapat penilaian positif dari Tim juri pada lomba kader posyandu sebagai inovasi baru dikota padang. Disamping itu adanya kelompok warga dikelurahan lain yang ingin mengembangkan budidaya tanaman Kelor dan olahan dari Kelor. Ditambah lagi adanya keinginan warga untuk mengembangkan Kelor dilahan kosong milik mereka.

\section{KESIMPULAN DAN SARAN}

Hasil kegiatan menunjukkan bahwa partisipasi masyarakat untuk pegembangan Kelor sangat besar, meskipun awal kegiatan 91,30\% belum mengetahui manfaat tanaman Kelor, ternyata $100 \%$ peserta akhirnya antusias untuk mengolah tanaman Kelor menjadi teh. Hasil kegiatan juga terbentuk KUB Beringin Sakti, untuk menjamin keberlanjutan program, yang telah memproduksi teh kelor kemasan $12 \mathrm{~g}$ dan $25 \mathrm{~g}$. Hasil kalkulasi pengolahan daun Kelor, dengan 40 batang Kelor, dapat meningkatkan pendapatan minimal Rp. 1 juta/bulan.

\section{UCAPAN TERIMAKASIH}

Terimakasih diucapkan Direktorat Jenderal Pembelajaran dan Kemahasiswaan, Kementrian Riset dan Teknologi, atas dana hibah Program Hibah Bina Desa Tahun 2018.

\section{DAFTAR PUSTAKA}

BPS. 2017. Kota Padang dalam Angka. Badan Pusat Statistik Sumatera Barat.

Fahrudin, A. 2012. Pemberdayaan, Partisipasi dan Penguatan Kapasitas Masyarakat. Humaniora, Bandung.

Gopalakrishnan, L., Doriya, K. and Kumar, D. S. 2016. 'Moringa oleifera: A review on nutritive importance and its medicinal application', Food Science and Human Wellness, 5, pp. 49-56. doi: 10.1016/j.fshw.2016.04.001.

Hernani and Raharjo, M. 2005. Tanaman Berkhasian Antioksidan. 1st edn, Penebar Swadaya. 1st edn. Penebar Swadaya, Jakarta.

Immy, S. R., Aryanti, E. and Suripto (2015) 'Phytochemical content of some of local plant species frequently used as raw materials for traditional medicin', in Seminar Nasional Masyarakat Biodiversity Indonesia, pp. 388-391. doi: $10.13057 / \mathrm{psnmbi} / \mathrm{m} 010237$. 
Mardikanto, T. 2014. CSR (Corporate Social Responsibility) (Tanggungjawab Sosial Korporasi). Alfabeta, Bandung.

Muhi, A. H. 2011. Perencanaan Pembangunan Desa. Alqa Print, Jatinangor Sumedang.

Najiati, S. 2005. Pemberdayaan Masyarakat di Lahan Gambut. Wetlands International, Bogor.

Novia, D. 2018 Introduksi teknologi pada IKM pengumpul dan pembuat kerupuk kulit di Padang. Jurnal Hilirisasi IPTEKS. 1(4) :99-109.

Oyeyinka, A. T. and Oyeyinka, S. A. 2016. Moringa oleifera as a food fortificant: Recent trends and prospects. Journal of the Saudi Society of Agricultural Sciences. Elsevier, Open acces. doi: 10.1016/J.JSSAS.2016.02.002.

Pasandaran, E.. 2006. Integrasi Tanaman Ternak di Indonesia. Badan penelitian dan Pengembangan Pertanian, Jakarta.

Purba, J. N. 2008. Pemberdayaan Masyarakat Desa di Kabupaten Simalungun. Tesis. Pascasarjana Universitas Sumatera Utara, Medan. 